\title{
The Influence of Transformational Leadership and Organizational Commitment on Innovative Behavior with Knowledge Management as Intervening Variables on the Millennial Generation in KAP Tanubrata Sutanto Fahmi Bambang dan Rekan (TSFBR)
}

\author{
Tini Yuliati and Lenny Christina Nawangsari
}

\section{ABSTRACT}

\begin{abstract}
This research aims to identify and examine the factors that influence transformational leadership and organizational commitment to innovative behavior through knowledge management in Millennial Generation in a public accounting firm in Jakarta. This study involved 129 millennial employees in the audit service industry. The data were analyzed using a quantitative approach because it prioritizes the measurement method and the sample using a deductive approach that emphasizes detailed priorities on the available data. This study found several measurement results on the object of research, namely transformational leadership has a positive and significant effect on knowledge management in the millennial generation, positive and significant organizational commitment to knowledge management in the millennial generation, positive and significant knowledge management on innovative behavior in the millennial generation, positive transformational leadership and significant to the innovative behavior of the millennial generation, positive and significant organizational commitment to innovative behavior, transformational leadership has a positive and significant influence on the innovative behavior of the millennial generation through knowledge management mediation, and positive and significant organizational commitment to the innovative behavior of the millennial generation through knowledge management.
\end{abstract}

Keywords: Innovative Behavior, Knowledge Management, Organizational Commitment, and Transformational Leadership.

\section{INTRODUCTION}

The client's need for financial statement audit services is currently getting higher. This is a challenge for public accounting firms to meet client needs at almost the same time or tight completion targets. Responding to this challenge, the office must improve employee competence, professional attitude, ability to adapt to very fast changes, and be creative and innovative in responding to work and challenges they face all the time. Competence is an ability, which is the concept of uniting knowledge and skills on various elements. Dimensions and indicators of competence are divided into three, namely, cognitive dimensions, social dimensions, and functional dimensions. The relationship between the three dimensions of competence is combined in a comprehensive understanding framework. Three dimensions have universal value and are described as the depth of knowledge [1], [2]. Employees who have innovative behavior are needed so that the company is always dynamic to achieve the targets that have been determined by the company [3].
Submitted : July 29, 2021

Published : August 31, 2021

ISSN: 2507-1076

DOI: $10.24018 /$ ejbmr.2021.6.4.1003

Tini Yuliati

Master of Management, Mercu Buana

University, Jakarta, Indonesia.

(e-mail: tyuliati2205@gmail.com)

Lenny Christina Nawangsari

Master of Management, Mercu Buana

University, Jakarta, Indonesia.

*Corresponding Author
The high level of competition in the external audit service industry makes company leaders require every employee to be pro-active in implementing new ideas in the company in terms of team management, the usage of audit tools that always evolving, exceptional client service, project completion agreed, team learning and so on. Employee creative performance and creativity are generally defined as the generation of novel and useful products, ideas, and procedures for innovation, which is beneficial for organizational growth and success [4]-[8]. Innovation in organizations can't be separated from the role of leaders in the organization [9]. Leaders who can motivate, will inspire, giving influence, and change the innovative behavior of members of the organization. Transformational leadership seeks to build an organization's ability to define the goals and to support changing development of learning practices [10], [11].

Based on interviews conducted by researchers at several manager levels, it was found that the low level of employee passion for work causes the employee's low innovative behavior in managing data and completing work at the Junior 
Auditor level. Employees who have a high passion will try hard to contribute new ideas at work, look for other alternatives, and be open-minded when facing problems. Managers are greatly helped by employees who have innovative behavior as mentioned above, especially during busy times with tight targets of work, limited time, and a large number of projects, but unfortunately there are not many junior levels like this.

This phenomenon is what researchers want to raise to find out more about the influence of transformational leadership, organizational commitment to innovative behavior through knowledge management where the majority of employees in the office are millennial generation employees. The advantages of the millennial generation are wanting to be fast, easy to change jobs in a short time, creative, dynamic, technology literate, close to social media [12] and according to [13], The millennial generation or generation $\mathrm{Y}$ (gen $\mathrm{Y}$ ) is a generation that has a birth year between 1980-1995.

\section{LITERATURE REVIEW AND HYPOTHESES}

\section{A. Influence of Transformational Leadership on} Knowledge Management

Research by [14] states that transformational leadership has an impact on increasing employee knowledge management. [15], stated that the role of transformational leaders is to create trust, a feeling of belonging, and knowledge sharing. Based on the description above, the following hypothesis can be formulated:

H1: Transformational Leadership has a positive and significant effect on Knowledge Management.

\section{B. Influence of Organizational Commitment on Knowledge Management}

Significant relationship between organizational commitment to knowledge transfer, in addition to the results of the study also showed that organizational commitment affects knowledge transfer and affects the level of maturity [16]. Affective committed employees are more willing to share knowledge and utilize the knowledge shared with them by their co-workers. Affective commitment and professional trust positively affect knowledge sharing [17]. Based on the description above, the following hypothesis can be formulated:

H2: Organizational commitment has a positive and significant effect on Knowledge Management.

\section{Influence of Knowledge Management on Innovative Behavior}

The process of innovation allows the creation of new knowledge that depends on the intelligence and creativity of the individual [18]. According to [19], knowledge sharing allows employees to access a variety of knowledge and information, which has an important impact on employee innovation itself. Knowledge Sharing has a significant influence on innovative behavior [20]. Based on the description above, the following hypothesis can be formulated:

H3: Knowledge management has a positive and significant effect on Innovative Behavior.

\section{Influence of Transformational Leadership on} Innovative Behavior

Leadership style is very influential in fertilizing the innovative behavior of its employees. Transformational leaders have a positive influence in enhancing organizational innovation [9]. Transformational leadership has a direct positive effect on innovation, so that to increase teacher innovativeness it is necessary to increase the effectiveness of transformational leadership [11]. Transformational leaders create a supportive workplace through inspiration, motivation, and individual consideration. Such a supportive environment effectively increases employee motivation to engage in initiating and implementing new ideas [21]. Based on the description above, the hypothesis can be formulated:

H4: Transformational Leadership has a positive and significant effect on Innovative Behavior.

\section{E. Influence of Organizational Commitment on Innovative Behavior}

Organizational commitment influences innovative behavior [22]. According to [23] that effective commitment is significantly more strongly positively related to employee innovation when team members share the perception that their supervisor enforces a leader's participation-oriented behavior. Based on the description above, the hypothesis can be formulated:

H5: Organizational Commitment has a positive and significant effect on Innovative Behavior.

\section{F. Influence of Transformational Leadership on Innovative Behavior through Knowledge Management}

Transformational leadership works best in team learning because it is involving the voluntary effort and initiative of all members. Team learning has a positive multi-level moderating effect on the relationship between transformational leadership and innovative behavior [24]. Based on the description above, the hypothesis can be formulated:

H6: Transformational Leadership has a positive and significant effect on Innovative Behavior through Knowledge Management.

\section{G. Influence of Organizational Commitment on Innovative Behavior through Knowledge Management}

Affective personal commitment becomes the motivation and emotional force that helps people to generate and implement new ideas [25]. The results of the research by [25] are that affective personal commitment has a direct influence on innovative performance through knowledge creation ability. Based on the description above, the hypothesis can be formulated:

H7: Organizational Commitment has a positive and significant effect on Innovative Behavior through Knowledge Management.

\section{RESEARCH METHODOLOGY}

The study was conducted using a quantitative approach which pays more attention to the measurement method and the sample using a deductive approach by emphasizing priority on data collection and more detailed analysis. This study uses quota sampling, where from the total 312 
employees, and 190 employees are millennial generation. Based on 190 millennial employees are taken of 129 employees of the millennial generation. [26] Sample is calculated using Slovin technique, with the following calculation:

$$
n=\frac{N}{1+N\left(e^{2}\right)}=\frac{190}{1+190\left(0.5^{2}\right)}=129
$$

where

$n=$ sample / total respondent;

$N=$ population;

$e=$ standard error of sample taken.

\section{RESEARCH RESULT AND DISCUSSION}

This study aims to determine the effect of transformational leadership and organizational commitment on innovative behavior through knowledge management on millennial generation among TSFBR employees. This research was conducted by distributing 129 copies of questionnaire data to TSFBR employee respondents and conducted online.

\begin{tabular}{|c|c|c|c|c|}
\hline Variable & Indicator & Min & Max & Mean \\
\hline \multirow{8}{*}{$\begin{array}{l}\text { Transformational } \\
\text { Leadership } \\
\text { (XI) }\end{array}$} & $\mathrm{X} 1.1$ & 1 & 5 & 3.729 \\
\hline & $\mathrm{X} 2.2$ & 1 & 5 & 3.845 \\
\hline & $\mathrm{X} 1.3$ & 1 & 5 & 3.698 \\
\hline & $\mathrm{X} 1.4$ & 1 & 5 & 4.054 \\
\hline & $\mathrm{X} 1.5$ & 1 & 5 & 3.783 \\
\hline & $\mathrm{X} 1.6$ & 1 & 5 & 3.845 \\
\hline & $\mathrm{X} 1.7$ & 1 & 5 & 3.783 \\
\hline & $\mathrm{X} 1.8$ & 1 & 5 & 3.829 \\
\hline \multicolumn{4}{|c|}{ Total Mean Value and Standard Deviation } & 3.821 \\
\hline \multirow{6}{*}{$\begin{array}{l}\text { Organization } \\
\text { Commitment } \\
\text { (X2) }\end{array}$} & $\mathrm{X} 2.1$ & 1 & 5 & 3.868 \\
\hline & $\mathrm{X} 2.2$ & 1 & 5 & 3.760 \\
\hline & $\mathrm{X} 2.3$ & 1 & 5 & 3.620 \\
\hline & $\mathrm{X} 2.4$ & 1 & 5 & 3.760 \\
\hline & $\mathrm{X} 2.5$ & 1 & 5 & 3.527 \\
\hline & $\mathrm{X} 2.6$ & 1 & 5 & 3.783 \\
\hline \multicolumn{4}{|c|}{ Total Mean Value and Standard Deviation } & 3.720 \\
\hline \multirow{10}{*}{$\begin{array}{l}\text { Knowledge } \\
\text { Management } \\
\text { (Y1) }\end{array}$} & Y1.1 & 1 & 5 & 3.930 \\
\hline & Y1.2 & 1 & 5 & 3.953 \\
\hline & Y1.3 & 1 & 5 & 3.853 \\
\hline & Y1.4 & 1 & 5 & 3.760 \\
\hline & Y1.5 & 1 & 5 & 3.705 \\
\hline & Y1.6 & 1 & 5 & 3.636 \\
\hline & Y1.7 & 1 & 5 & 3.667 \\
\hline & Y1.8 & 1 & 5 & 3.636 \\
\hline & Y1.9 & 1 & 5 & 3.775 \\
\hline & $\mathrm{Y} 1.10$ & 1 & 5 & 3.806 \\
\hline \multicolumn{4}{|c|}{ Total Mean Value and Standard Deviation } & 3.821 \\
\hline \multirow{8}{*}{$\begin{array}{l}\text { Innovative } \\
\text { Behavior } \\
\text { (Y2) }\end{array}$} & $\mathrm{Y} 2.1$ & 1 & 5 & 3.868 \\
\hline & $\mathrm{Y} 2.2$ & 1 & 5 & 3.729 \\
\hline & Y2.3 & 1 & 5 & 3.853 \\
\hline & Y2.4 & 1 & 5 & 3.822 \\
\hline & Y2.5 & 1 & 5 & 3.837 \\
\hline & Y2.6 & 1 & 5 & 3.775 \\
\hline & Y2.7 & 1 & 5 & 3.628 \\
\hline & Y2.8 & 1 & 5 & 3.822 \\
\hline \multicolumn{4}{|c|}{ Total Mean Value and Standard Deviation } & 3.792 \\
\hline
\end{tabular}

Based on the table describes the responses of respondents to all variables, namely:

1) The transformational leadership variable in the $X 1.4$ indicator has the highest mean value of 4,054 , this shows that
$81.08 \%$ of respondents agree that leader at KAP TSFBR involves the team in unifying the organization's vision.

The lowest mean value is 3,698 or $73.96 \%$ of respondents agree that leaders motivate and inspire subordinates on the dimensions to increase employee motivation.

2) The organizational commitment variable on the $X 2.1$ indicator has the highest mean value of 3.868 , meaning that $77.36 \%$ of respondents agree that organizational commitment involves a very strong emotional attachment to the dimension of affective commitment.

The lowest mean value is 3,527, which means that $70.54 \%$ of respondents agree that TSFBR's KAP organizational commitment motivates and inspires subordinates on the inspirational motivation dimension.

3) The knowledge management variable on the Y1.2 indicator has the highest mean value of 3.953 , meaning that it shows $79.06 \%$ of respondents agree that knowledge management asks for external sources of knowledge for organizational needs on the acquisition dimension. The lowest mean value is the Y1.6 indicator with a value of 3.636, or $72.72 \%$ of respondents agree that knowledge management has been integrated into a system on the storage dimension.

4) The innovative behavior variable on the Y2.1 indicator has the highest mean value of 3,868 , based on statistical data above the value of the highest mean is 3,868 or $77.36 \%$ of respondents agree that the opportunities and space provided by superiors to innovate at work will increase employees' innovative behavior at work. The lowest mean value is 3.628 or $72.56 \%$ of respondents agree that the ideas of employees in doing their work will increase the innovative behavior of employees.

Hypothesis results based on testing using SEM-PLS based on the structural evaluation model (inner model).

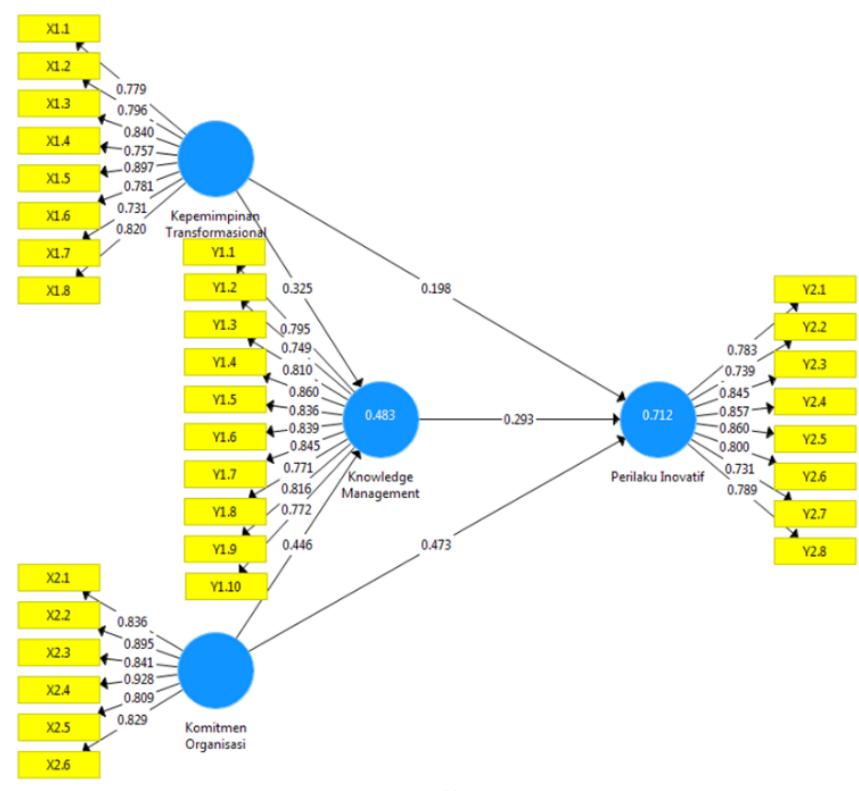

Fig. 1. Path Coefficients Results

Based on the results of the t-test in table 4.13, shows that transformational leadership is significantly positive for knowledge management as indicated by the parameter coefficient of 0.325 , the significance value of 0.000 is smaller than the $5 \%$ alpha level. This is evidenced by the T-statistic value of 3,648 which is greater than 1,989 (t-table), based on these results, it can be concluded that the first hypothesis is accepted. 
TABLE II: PATH COEFFICIENTS RESULTS

\begin{tabular}{|c|c|c|c|c|}
\hline No & Hypothesis & T Stat & P Values & Result \\
\hline H1 & $\begin{array}{l}\text { Transformational Leadership - } \\
>\text { Knowledge Management }\end{array}$ & 3.648 & 0.000 & Accepted \\
\hline $\mathrm{H} 2$ & $\begin{array}{l}\text { Organization Commitment -> } \\
\text { Knowledge Management }\end{array}$ & 5.290 & 0.000 & Accepted \\
\hline H3 & $\begin{array}{l}\text { Knowledge Management -> } \\
\text { Innovative Behavior }\end{array}$ & 3.713 & 0.000 & Accepted \\
\hline $\mathrm{H} 4$ & $\begin{array}{c}\text { Transformational Leadership - } \\
\text { > Innovative Behavior }\end{array}$ & 2.702 & 0.007 & Accepted \\
\hline H5 & $\begin{array}{c}\text { Organization Commitment -> } \\
\text { Innovative Behavior }\end{array}$ & 6.397 & 0.000 & Accepted \\
\hline H6 & $\begin{array}{l}\text { Transformational Leadership - } \\
>\text { Knowledge Management }-> \\
\text { Innovative Behavior }\end{array}$ & 2.603 & 0.010 & Accepted \\
\hline $\mathrm{H} 7$ & $\begin{array}{c}\text { Organization Commitment -> } \\
\text { Knowledge Management }-> \\
\text { Innovative Behavior }\end{array}$ & 2.686 & 0.007 & Accepted \\
\hline
\end{tabular}

Significant positive organizational commitment to knowledge management is indicated by the parameter coefficient of 0.446 , the significance value of 0.000 is smaller than the $5 \%$ alpha level. This is evidenced by the T-statistic value of 5,290 which is greater than 1989 (t-table), based on these results, it can be concluded that the second hypothesis is accepted.

Then, the knowledge management variable is significantly positive for innovative behavior as indicated by the parameter coefficient of 0.293 , the significance value of 0.000 is smaller than the $5 \%$ alpha level. This is evidenced by the T-statistic value of 3,713 which is greater than 1,989 (t-table), based on these results, it can be concluded that the third hypothesis is accepted.

In the fourth hypothesis, the transformational leadership variable is significantly positive on innovative behavior as indicated by the parameter coefficient of 0.198 , the significance value of 0.007 is smaller than the 5\% alpha level. This is evidenced by the T-statistic value of 2,702 which is greater than 1,989 (t-table), based on these results, it can be concluded that the fourth hypothesis is accepted.

The next variable, organizational commitment is significantly positive on innovative behavior as indicated by the parameter coefficient of 0.473 , the significance value of 0.000 is smaller than the $5 \%$ alpha level. This is evidenced by the value of T-statistic of 6,397 is greater than 1,989 (t-table), based on these results, it can be concluded that the fifth hypothesis is accepted.

The results of the indirect effect hypothesis testing indicate that transformational leadership is significantly positive on innovative behavior through knowledge management as indicated by the parameter coefficient of 0.095 , the significance value of 0.010 is smaller than the $5 \%$ alpha level. This is evidenced by the T-statistic value of 2,603 which is greater than 1,989 (t-table), based on these results, it can be concluded that the sixth hypothesis is accepted.

\section{CONCLUSIONS AND SUGGESTIONS}

Based on the results of research and discussion that have been described in the previous chapter, it can be concluded that the results of the study are as follows:

1) Transformational Leadership has a positive and significant impact on Knowledge Management in the millennial generation at KAP TSFBR. This shows that the leadership factor with integrity, rationality, and problem solver will support science to be managed in an integrated manner.

2) Organizational commitment has a positive and significant effect on knowledge management in the millennial generation at KAP TSFBR. This shows that the ownership factor for the company will support appreciation to employees for their achievements in their duties and responsibilities.

3) Knowledge management has a positive and significant impact on the Millennial Generation's Innovative Behavior at KAP TSFBR. This shows that the factor seeking knowledge sources from external to the organization will get support from the team to pro-actively add knowledge from outside the office.

4) Transformational leadership has a positive and significant influence on the Millennial Generation's Innovative Behavior at KAP TSFBR. This shows that the leader must focus on individual strengths and will be supported by the application of the ideas of the team to his work.

5) Organizational commitment has a positive and significant influence on the Millennial Generation's Innovative Behavior at KAP TSFBR. This shows that the factor responsible for work will be supported by increasing the managerial skills of superiors in managing the team so that the team gets clear, objective directions and always encourages the team to behave innovatively at work.

6) Transformational Leadership has a positive and significant influence on Innovative Behavior through Knowledge Management mediation in the millennial generation at KAP TSFBR. This shows that motivating and inspiring factors for feed subordinates are supported by increased employee training which is needed to provide opportunities and space for employees so that they can be more innovative in carrying out their work.

7) Organizational commitment has a positive and significant influence on innovative behavior through the mediation of millennial generation knowledge management at KAP TSFBR. This shows that employee loyalty to the company needs to be considered through the trust and opportunities given to lead employees to share knowledge as trainers and management to give appreciation both financially and non-financially.

The author feels that there are still many weaknesses in this research. The limitation of this research is the questionnaire data collection is carried out during the auditor's high session in pandemic conditions and work from home policy so that the authors need a long time to follow up on the questionnaire to the respondents. For other writers, if they need research, such as auditors, the implementation time can be adjusted during the auditor's low session, approximately from May to October. In addition, for further research, it is recommended to develop research on knowledge management variables that mediate organizational commitment because previous research on this journal is still very limited. This is revealed in the research of [25].

\section{REFERENCES}

[1] Le Deist F.D., Winterton J. and Stringfellow, (2006), Typology of knowledge, skills and competences: Clarification of the concept and 
prototype. European Centre for the Development of Vacational Training, Vol. 64, 3048, 1-121.

[2] Nawangsari L.C. \& Sutawidjaya A.H., (2019) Talent Management in Mediating Competencies and Motivation to Improve Employee's Engagement, International Journal of Economics and Business Administration, Volume VII, Issue I, 2019.

[3] Nardo R., Evanita S., \& Syahrizal, (2018), The influence of Transformational Leadership and Non-physical Working Environment on Innovative Behavior, Padang State University, Indonesia.

[4] Amabile T.M. (1988), "A model of creativity and innovation in organizations", Research in Organizational Behavior, Vol. 10 No. 10, pp, 123-167.

[5] Henker N., Sonnentag S. and Unger D. (2015), "Transformational leadership and employee creativity: the mediating role of promotion focus and creativity process engagement", Journal of Business and Psychology, Vol. 30. No. 2, pp. 235-247.

[6] Jiang, W., Gu, Q. and Tang, T.L.P. (2019), "Do victims of supervisor bullying suffer from poor creativity? Social cognitive and social comparison perspectives", Journal of Business Ethic, Vol. 157 No. 33, pp.865-884.

[7] Tse Herman H.M., March, L., To and Warren, C.K.C. (2018), "When and why does transformational leadership influence employee creativity? The roles of personal control and creative personality", Human Resource Management, Vol. 57 No. 1, pp.145-157.

[8] Ma X., Jiang W., Wang L., \& Xiong J., (2020), A Curvilinear Relationship Between Transformational Leadership and Employee Creativity, DOI 10.1108/MD-07-2017-0653.

[9] Parashakti R.D, Rizki M. \& Saragih L., (2019), The influence of Transformational Leadership and Organizational Culture on Employee Innovative Behavior, Journal of Theory and Applied Management, No. 2.

[10] Hallinger H., (2013), Transformational Approach to Scholl Leadership: Contribution to Continued Improvement of Education. Journal of Change and Leadership, (17), 239.

[11] Pestalozi D., Erwandi R. \& Putra M.R.E. (2019), The influence of Transformational Leadership on Teachers Innovativeness of State Senior High School, Lubuklinggau, Journal of Administration and Educational Management, Vol. 2 No. 1.

[12] Sebastian Y, 2016, "Langgas Generation of Indonesian Millennial", Jakarta, Publisher of Gagas Media.

[13] Andrea B., Gabriella H.C. \& Timea J., (2016), Y and Z Generations at Workplaces, Journal of Competitiveness, Vol. 8, Issue 3, pp. 90-106.

[14] Hadiman I.N., Sujono, and Adam L.O.B. (2019), The influence of Organizational Culture and Transformational Leadership on Knowledge Management of Bank North Sulawesi Employees, Journal of Management and Entrepreneurship, ISSN: 2685-5151, Vol. 11 No. 2 .

[15] Yadav M., Choudhary S. \& Jain S., (2018), Transformational Leadership and Knowledge Sharing Behavior in Freelancers. A Moderated Mediation Model with Employee Engagement and Social Support, Journal of Global Operations \& Strategic Sourcing, DOI 10.1108/JGOSS-08-2017-0030.

[16] Marques J.M.R., Falce J.L.L., Forsenca F.M.R.M., Muylder C.F.D., Silva J.T.M, (2018), The Relationship Between Organizational Commitment, Knowledge Transfer and Knowledge Management Maturity, Journal of Knowledge Management, DOI.10.1108/JKM-032018-0199.

[17] Ouakouak M.L \& Ouedraogo N., (2018), Fostering Knowledge Sharing and Knowledge Utilization. The Impact of Organizational Commitment and Trust, Business Process Management Journal, DOI 10.1108/BPMJ-05-2017-0107.

[18] Rahmahthia S.E. \& Etikariena A. (2019), The Effect of Knowledge Sharing Behavior on Innovative Behavior in the Workplace of Employees of PT X and PT Y, Journal of Psychogenesis, Vol. 7 No. 2.

[19] Zhao S., Jiang Y., Peng X. \& Hing J., (2020), Knowledge Sharing Direction and Innovation Performance in Organizations. Do Absorptive Capacity and Individual Creativity Matters, European Journal of Innovation Management, DOI.10.1108/EJIM-09-20190244 .

[20] Mazidah A. \& Laily N. (2019), The Effect of Knowledge Sharing on Innovative Behavior and Employee Performance, Journal of Management Science \& Research, e-ISSN:2461-0591.

[21] Afsar B., Masood M. \& Umrani W.A., (2019), The Role of Job Crafting and Knowledge Sharing on the Effect of Transformational Leadership on Innovative Work Behavior, Personnel Review, Vol. 48 No. 5.

[22] Dahri N.W. \& Aqil M., (2018), Organizational Culture, Job Satisfaction and Organizational Commitment in Improving Innovative Behavior, Journal of Business Theory \& Implementation, Vol. 9 No. 2.

[23] Odoardi C, Battistelli A., Montani F., \& Peiro J.M., (2019), Affective Commitment, Participative Leadership, and Employee Innovation: A
Multilevel Investigation, Journal of Work and Organizational Psychology, Vol. 35, No. 2 pp. 103-113.

[24] Chung D.S., \& Li J.M., (2018), Curvilinear Effect of Transformational Leadership on Innovative Behavior Among R\&D Teams in South Korea. Moderating Role of Team Learning, Journal of Organizational Change Management.

[25] Sarwat N. \& Abbas M., (2020), Individual Knowledge Creation Ability: Dispositional Antecedents and Relationship to Innovative Performance, European Journal of Innovation Management, DOI 10.1108/EJIM-05-2020-0198.

[26] Sugiyono, 2014, Quantitative Qualitative Research Methodology, R and D, Alfabeta, Bandung, Indonesia. 